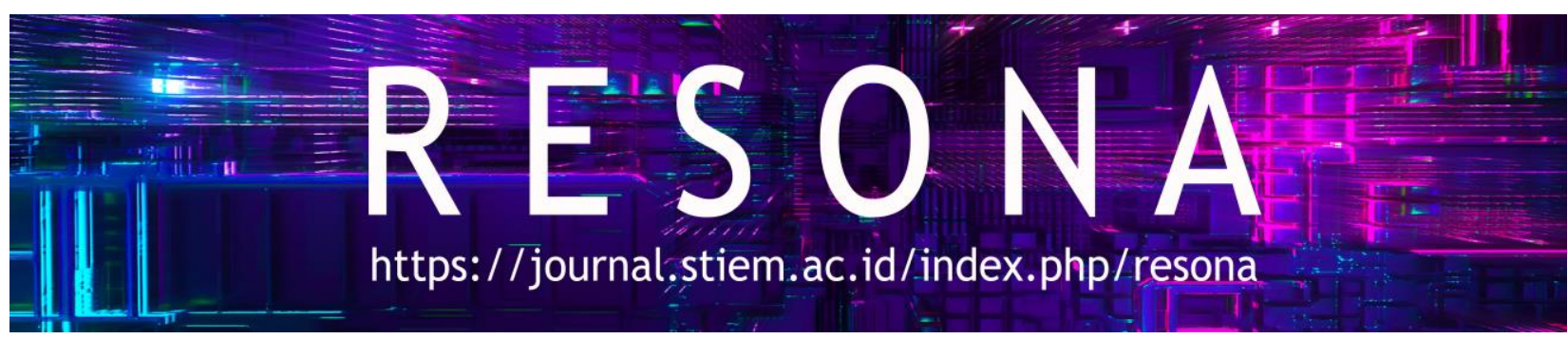

\title{
MODEL SUPERVISI AKADEMIK PENGAWAS DALAM MENINGKATKAN KOMPETENSI GURU TAMAN KANAK-KANAK DI KOTA PALOPO
}

\author{
Hajeni $^{1}$, Abdul Kadir ${ }^{2}$, Nurwahidin Hakim ${ }^{3}$ \\ ${ }^{1,2,3}$ universitas Muhamadiyah Palopo
}

\begin{tabular}{l} 
INFO NASKAH \\
\hline Diserahkan 25 Oktober 2019 \\
Diterima \\
O1 November 2019 \\
Diterima dan Disetujui 27 \\
Desember 2019 \\
Kata Kunci: \\
Model Supervisi Akademik \\
Pengawas, \\
Kompetensi guru Taman Kanak- \\
Kanak \\
Abstrack: \\
Academic Supervision model, \\
Kindergarten \\
Competencies
\end{tabular}

INFO NASKAH

Diterima

01 November 201

Desember 2019

\begin{abstract}
ABSTRAK
Penelitian ini termasuk dalam jenis penelitian kualitatif dengan pendekatan deskriptif. Adapun pendekatan yang digunakan yaitu pendekatan fungsi manajemen, bertujuan untuk: 1) mendeskripsikan model supervisi akademik pengawas dalam meningkatkan kompetensi guru Taman Kanak-kanak di Kota Palopo (2) mengetahui usaha pengawas dalam meningkatkan kompetensi guru Taman Kanak-kanak di Kota Palopo (3) menentukan faktor pendukung dan penghambat pelaksanaan supervisi akademik pengawas pada Taman Kanakkanak di Kota Palopo. Hasil penelitian ini menunjukkan bahwa: (1) Model Supervisi yang digunakan adalah model supervisi tradisional/konvensional. (2) Usaha yang dilakukan pengawas untuk meningkatkan kompetensi guru Taman Kanak-kanak di Kota Palopo belum maksimal karena tindak lanjut hasil supervisi. (3) Kendala tidak maksimalnya pelaksanaan supervisi oleh pengawas karena ketidaksiapan guru untuk disupervisi baik dari segi mental maupun kelengkapan administrasi. Penelitian berimplikasi pada perbaikan model supervisi akademik pengawas untuk meningkatkan kompetensi guru Taman Kanak-kanak di Kota Palopo, peningkatan usaha pengawas dalam meningkatkan kompetensi guru Taman Kanak-kanak di Kota Palopo serta meminimalisir faktor penghambat pelaksanaan supervisi akademik pengawas pada guru Taman Kanak-kanak di Kota Palopo. Secara praktis, perlu peningkatan kompetensi pengawas, terutama kompetensi supervisi akademik yang berkaitan dengan peningkatan kualitas guru dan kualitas pembelajaran.
\end{abstract}

\begin{abstract}
This research is qualitative research with a descriptive approach. The approach used is the management function approach, aimed at describing the supervisory, knowing supervisors' efforts to enhance the competency of kindergarten teachers and determine the supporting and inhibiting factors for the implementation of supervisory, academic supervision in kindergarten in Palopo City. The results of this study indicate that the Supervision Model used is a traditional/conventional supervision model which has not maximized yet. The second, Efforts by supervisors to improve the competency of kindergarten teachers have not been maximized because the follow-up to supervision results is only carried out by supervisors in the form of teacher working groups. The last result is about the obstacles, they were not the maximum implementation because teachers did not prepare to be supervised. The research has implications for improving the supervisory, academic supervision model to enhance the competency of kindergarten teachers in Palopo City, increasing supervisors' efforts to strengthen the competence of kindergarten teachers in Palopo City and minimizing the inhibiting factors for the implementation of supervisory, academic supervision on Kindergarten teachers in the City Palopo. Practically, it is necessary to increase the competency of supervisors, especially academic supervision competencies related to improving the quality of teachers and the quality of learning.
\end{abstract}




\section{Pendahuluan}

Pengawas adalah guru yang diangkat oleh pihak yang berwenang untuk melakukan pembinaan dan pemberian bimbingan kepada guru dalam mengelola proses pembelajaran. Hal ini sejalan dengan definisi pengawas sekolah menurut Permendiknas Nomor 12 Tahun 2007, pengawas sekolah adalah guru yang diangkat dan diberi tugas, tanggung jawab dan wewenang secara penuh oleh pejabat yang berwenang untuk melakukan pengawasan pendidikan di sekolah dengan melaksanakan penilaian dan pembinaan dari segi teknis pendidikan dan administrasi pada satuan pendidikan prasekolah, sekolah dasar dan sekolah menengah. Pengawas berasal dari guru yang dianggap memiliki kapasitas keilmuan dan pengalaman dalam mengelola pembelajaran.

Pengawasan merupakan salah satu fungsi manajemen selain dari perencanaan, pengorganisasian dan pelaksanaan. Pendapat yang sama juga dikemukan oleh Wukir dalam bukunya Manajemen Sumber Daya Manusia dalam Organisasi Sekolah Fungsi pengawasan dalam pendidikan dilaksanakan oleh pengawas sekolah dengan menjalankan tugas supervisi (Wukir, 2013). Menurut Boardman, supervisi adalah suatu usaha menstimulasi, mengkoordinasi, dan membimbing secara kontinu pertumbuhan guru-guru di sekolah baik secara individual maupun secara kolektif, agar lebih mengerti dan lebih efektif dalam mewujudkan seluruh fungsi pengajaran (Fathurohman, 2011). Supervisi pendidikan tidak hanya dilaksanakan oleh pengawas yang ditunjuk oleh Dinas Pendidikan, tetapi kepala sekolah dan guru-guru senior juga dapat bertindak sebagai supervisor pendidikan. (Novi mayasari, 2016).

Salah satu fungsi supervisi yaitu pengawasan. Pengawasan dalam hal ini dapat bermakna memperhatikan atau mengevaluasi pelaksanaan kegiatan yang telah direncanakan demi pencapaian tujuan (Sahertian, 2010). Membahas tentang pengawas, maka akan menyentuh tugas pokok bagi pengawas. Tugas pokok bagi pengawas yaitu melakukan monitoring, penilaian, pembinaan dan evaluasi bagi kepala sekolah dan guru demi pengembangan kualitas sekolah, kinerja kepala sekolah, guru dan seluruh staf sekolah. Fungsi supervisi yang dilakukan oleh pengawas, terdiri atas supervisi manajerial dan supervisi akademik. Namun pada kenyataannya, kegiatan supervisi yang dilakukan oleh para pengawas, belum menyentuh peningkatan kemampuan profesionalisme kepala sekolah dan guru. Peningkatan pengetahuan dalam bidang administrasi, manajemen dan kepemimpinan sekolah sama sekali belum terlihat dalam kegiatannya. 


\section{Masalah}

Berdasarkan hasil observasi awal yang penulis lakukan, pada taman kanak-kanak di Kota Palopo, penulis menemukan beberapa permasalahan sebagai berikut: (1) Banyak guru taman kanak-kanak yang belum memenuhi standar kualifikasi S1. Sebagian besar adalah lulusan SMA dan sebagian yang lain S1 namun bukan dari Program Studi Pendidikan Anak Usia Dini (PAUD), sehingga hal ini berpengaruh pada kompetensi yang dimiliki guru terutama kompetensi pedagogik yang berkaitan dengan proses pembelajaran, bagaimana merancang pembelajaran, melaksanakan pembelajaran dengan metode yang tepat dan melakukan penilaian terhadap hasil belajar. (2) Kurangnya kegiatan pelatihan bagi guru taman kanak-kanak, dan keterbatasan dana untuk mengikuti pelatihan tersebut. (3) Pelaksanaan supervisi pengawas di Kota Palopo dalam bentuk kunjungan kelas (supervisi akademik) ke setiap sekolah tidak dilaksanakan secara rutin. Kunjungan supervisi terpadu hanya dilaksanakan maksimal 2 kali dalam satu semester, bahkan terkadang dalam satu semester terdapat sekolah yang tidak pernah mendapat kunjungan dari pengawas. (4) Kehadiran pengawas di sekolah hanya untuk memeriksa kelengkapan perangkat pembelajaran guru dengan membawa format penilaian kinerja guru kemudian memeriksa kelengkapan administrasi guru berdasarkan format tersebut. (5) Waktu yang digunakan pengawas untuk melakukan supervisi ke setiap sekolah-sekolahpun terbatas, sehingga pengawas tidak memiliki cukup waktu untuk melakukan pembinaan terhadap kepala sekolah dan guru. Pengawas seringkali memeriksa perangkat pembelajaran tanpa memberi tindak lanjut terhadap hasil temuannya. Kegiatan supervisi pengawas terkesan hanya untuk menilai atau mencari kesalahan yang dilakukan oleh para kepala sekolah dan guru.

\section{Metode}

Penelitian yang digunakan adalah menggunakan pendekatan kualitatif dengan metode deskriptif. Proses pengumpulan data melalui observasi, wawancara, dan studi dokumentasi. Sedangkan keabsahan data melalui Triangulasi. Lokasi penelitian dilaksanakan pada pengawas taman kanak-kanak di Kota Palopo. Yang terdiri atas 6 informan Pengawas taman kanak-kanak, 3 informan Kepala Sekolah dan 2 informan guru Taman Kanak-kanak di Kota Palopo. Adapun pemilihan subjek pada penelitian ini adalah orang-orang yang memahami dan mengetahui dan serta menjadi pelaku dalam kegiatan supervisi akademik yang dapat memberikan informasi berkaitan dengan penelitian ini yaitu: Pengawas TK, Kepala sekolah TK, dan Guru TK. 


\section{Hasil dan Pembahasan}

\section{Gambaran Umum Pendidikan Taman Kanak-Kanak Di Kota Palopo}

Pendirian lembaga Pendidikan Anak Usia Dini mengalami perkembangan pesat. Hal ini berkaitan dengan 7 dimensi Kota Palopo, salah satunya adalah kota pendidikan dengan tujuan “terciptanya sumber daya manusia kota Palopo yang handal, terampil, profesional dan mandiri dalam menggali, mengembangkan dan memanfaatkan ilmu pengetahuan dan teknologi demi kesejahteraan umat manusia dan alam sekitarnya." Pendidikan yang dimaksud tidak hanya pendidikan Dasar, Sekolah Menengah Pertama, Sekolah Menengah Umum dan Perguruan Tinggi, tetapi tak kalah pentingnya adalah pendidikan anak Usia dini.

Keberadaan lembaga pendidikan anak usia dini di Kota Palopo, merupakan implementasi dari program pembangunan pemerintah. Hal ini dibuktikan dengan berdirinya TK, KB, TPA dan SPS di kota Palopo, jumlah taman kanak-kanak yang ada di Kota Palopo hingga tahun 2016, berjumlah 83 Sekolah, 295 guru yang terdiri dari 70 guru PNS dan 225 guru Non PNS dan 3.057 siswa, Keterangan selanjutnya mengenai jumlah TK, KB, TPA dan SPS tersebut dapat dilihat pada tabel berikut ini:

Tabel 1

Keadaan Jumlah Sekolah Taman Kanak-Kanak se-Kota Palopo

\begin{tabular}{|c|c|c|c|c|c|c|}
\hline \multirow{2}{*}{ No. } & \multirow{2}{*}{$\begin{array}{c}\text { Tahun } \\
\text { Ajaran }\end{array}$} & \multirow{2}{*}{$\begin{array}{c}\text { Sumlah } \\
\text { Sekolah }\end{array}$} & \multicolumn{3}{|c|}{ Jumlah Guru } & Jumlah \\
\cline { 5 - 6 } & & PNS & Non PNS & Jumlah & Siswa \\
\hline 1. & $2012 / 2013$ & 61 Sekolah & 117 & 206 & 323 & 2481 \\
\hline 2. & $2013 / 2014$ & 58 Sekolah & 106 & 197 & 303 & 2307 \\
\hline 3. & $2014 / 2015$ & 71 Sekolah & 84 & 172 & 256 & 2692 \\
\hline 4. & $2015 / 2016$ & 80 Sekolah & 83 & 213 & 296 & 2823 \\
\hline 5. & $2016 / 2017$ & 83 Sekolah & 70 & 225 & 295 & 3057 \\
\hline
\end{tabular}

Sumber data: Arsip data Sekolah Taman Kanak-kanak Kepala Bidang PAUDNI Kota Palopo.

\section{Model Supervisi Akademik Pengawas pada Guru Taman Kanak-kanak di Kota Palopo}

a. Deskripsi Model Pelaksanaan Supervisi Akademik Pengawas pada Guru Taman Kanak-kanak di Kota Palopo

1) Model Supervisi Akademik Pengawas I

Berdasarkan hasil wawancara, observasi dan studi dokumentasi, pelaksanaan supervisi akademik pengawas pada guru TK Aisyiyah I dan TK Kristen Palopo, peneliti 
menemukan data bahwa pelaksanaan supervisi akademik pengawas I pada TK Aisyiyah I dilakukan dengan tahap, pra-observasi, pelaksanaan atau observasi selanjutnya refleksi atau tindak lanjut. Adapun model supervisi akademik pengawas I dapat digambarkan sebagai berikut:

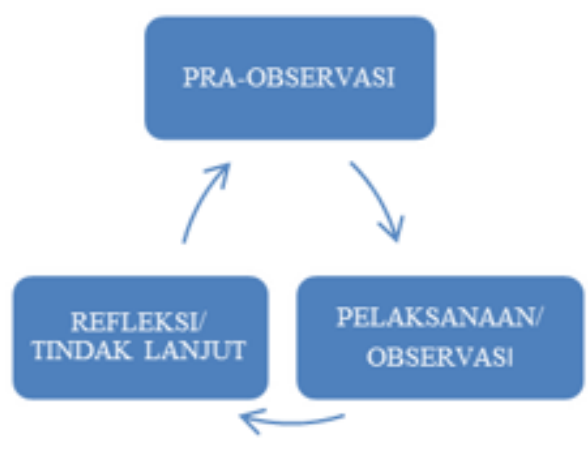

\section{Gambar 1 Model Supervisi Akademik Pengawas I}

Perencanaan dilakukan pengawas I dengan menyusun program supervisi pengawas berupa program tahunan, program semester, program pembentukan Kelompok Kerja Guru (KKG) dan Kelompok Kerja Kepala Sekolah (K3S) serta program-program kegiatan yang disusun pada awal semester. Sebagaimana yang disampaikan pengawas I ketika dilaksanakan wawancara tanggal 6 Desember 2016, menyatakan bahwa: "untuk kepengawasan ada program yang kita susun, di wilayah saya ada program tahunan dan program persemester, ada program evaluasi seperti.

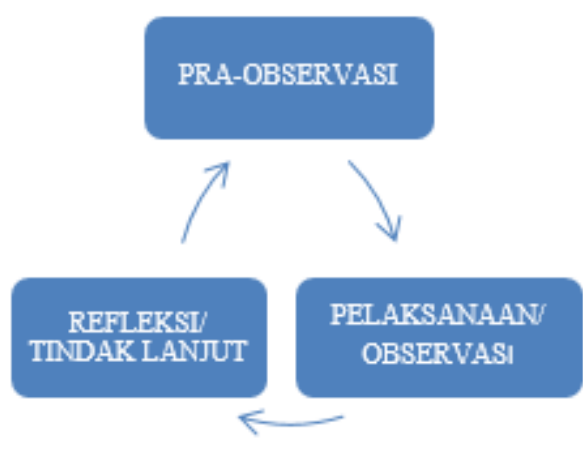

\section{Gambar 2 Model Supervisi Akademik Pengawas II}

Hasil wawancara terhadap pengawas II menggambarkan bahwa kegiatan supervisi pengawas dimulai pada awal tahun ajaran baru, pengawas II berkunjung untuk memantau kondisi sekolah yang merupakan sekolah binaannya kemudian menyusun program supervisi yang berkaitan dengan program manajerial sekolah dan akademik 
sekolah, serta menyusun program tahunan, program semester, Rencana Pelaksanaan Pembelajaran Mingguan (RPPM), dan Rencana Pelaksanaan Pembelajaran Harian (RPPH).

Hasil wawancara yaitu: Pelaksanaan supervisi atau observasi pelaksanaan pembelajaran dilakukan pengawas II dengan mengamati guru mempersiapkan alat pembelajaran, mengamati cara penyampaian pembelajaran, apakah sesuai dengan RPPH atau tidak. Selanjutnya pada tahap refleksi atau tindak lanjut, pengawas mengadakan pembinaan pada pertemuan Kelompok Kerja Guru (KKG), yang dilaksanakan setiap minggu.

Model Supervisi Akademik Pengawas III Hasil observasi, wawancara, dan studi dokumentasi, pelaksanaan supervisi akademik pengawas III pada TK Al-Kahfi, TK Dian Gita dan TK Aisyiyah I Kota Palopo, menggambarkan bahwa supervisi pengawas dilaksanakan melalui 3 tahap, yaitu pra-observasi dengan melaksanakan supervisi administrasi pembelajaran, selanjutnya pelaksanaan atau observasi dan refleksi/ tindak lanjut. Adapun pelaksanaan supervisi tersebut dapat digambar pada bagan di bawah ini.

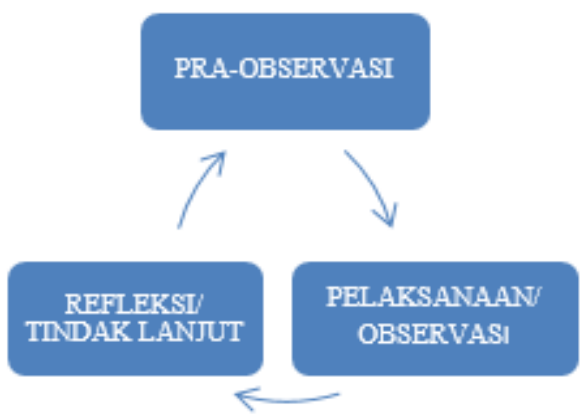

\section{Gambar 3 Model Supervisi Akademik Pengawas III}

Wawancara peneliti terhadap pengawas III, menggambarkan bahwa pada tahap perencanaan, dilakukan pengawas dengan mengadakan kunjungan awal atau observasi awal ke sekolah yang termasuk dalam wilayah III berdasarkan Surat Tugas Kepala Dinas Pendidikan Kota Palopo Tentang Pembagian Tugas Kepengawasan, kemudian menyusun program kepengawasan berdasarkan hasil kunjungan tersebut. Sebagaimana yang dijelaskan pengawas III bahwa "apabila saya mau mengadakan supervisi, sebelumnya saya mengunjungi sekolah yang menjadi binaan saya kemudian menyusun program berdasarkan hasil kunjungan tersebut. Kunjungan itu saya laksanakan setiap awal semester apabila tidak ada perubahan kepengawasan. 
Berdasarkan instrumen supervisi pelaksanaan pembelajaran guru di kelas, yang menjadi temuan pengawas yaitu yang pertama, pada kegiatan pendahuluan berupa apersepsi dan motivasi, guru tidak menyampaikan manfaat materi kepada anak, guru tidak mendemonstrasikan sesuatu yang terkait dengan tema, selanjutnya guru tidak menyampaikan kemampuan yang akan dicapai peserta didik. Selanjutnya, pada kegiatan inti, kemampuan guru mengaitkan materi dengan pengetahuan lain yang relevan, perkembangan iptek, dan kehidupan nyata tidak lakukan guru. Sedangkan pada kegiatan penutup, guru tidak memberikan tes lisan atau tulisan kepada anak.

Adapun hal pertama yang dilakukan pengawas adalah memberikan kesempatan kepada guru untuk mengungkapkan pendapat terkait cara guru mengajar mulai dari kegiatan awal, inti dan kegiatan akhir, dan menyampaikan hal-hal yang menjadi kendala dalam pelaksanaan pembelajaran. Selanjutnya pengawas menyampaikan kepada guru mengenai hasil pengamatan pelaksanaan pembelajaran, apakah kompetensi yang akan dicapai pada pembelajaran tersebut tercapai atau tidak. Hal yang masih kurang dari guru, sebagaimana yang dijelaskan pengawas III, bahwa, kegiatan pembelajaran guru masih perlu ditingkatkan dari aspek saintifik yang merupakan ciri khas kurikulum 13, kemudian penggunaan media pembelajaran juga masih perlu ditingkatkan, selanjutnya cara guru bertanya kepada siswa untuk membangkitkan rasa keingintahuan masih perlu perbaikan karena yang lebih aktif mengajukan pertanyaan adalah guru bukan siswa, kegiatan pembelajaran guru masih bersifat klasikal.

Model Supervisi Akademik Pengawas IV. Hasil observasi dan wawancara terhadap pengawas IV menggambarkan bahwa supervisi yang dilakukan pengawas IV melalui tahap pra observasi, observasi dan refleksi. Pelaksanaan supervisi akademik pengawas IV dapat digambarkan pada bagan berikut.

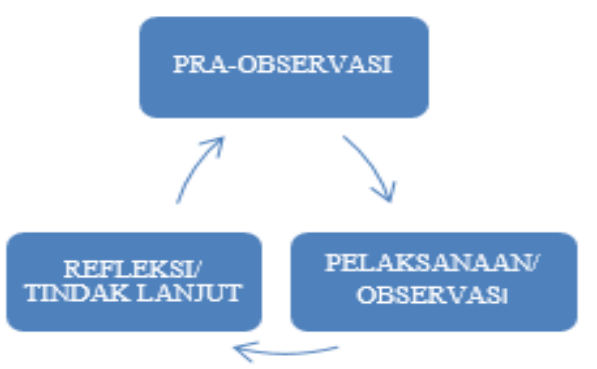

Gambar 4 Model Supervisi Akademik Pengawas IV 
Hasil wawancara dengan pengawas menjelaskan bahwa kegiatan supervisi dimulai dengan perencanaan yang dilakukan pengawas IV dengan berkunjung ke setiap sekolah binaan, selanjutnya mengadakan pertemuan di TK inti untuk pembentukan kepengurusan K3S dan KKG. Pengawas IV menjelaskan bahwa beliau melakukan pemantauan proses pembelajaran di sekolah binaan dengan memeriksa perangkat pembelajaran guru dan mengamati guru mengajar.

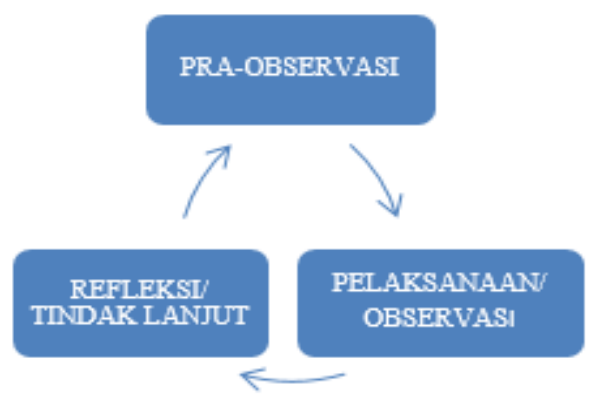

\section{Gambar 5 Model Supervisi Akademik Pengawas V}

Hasil wawancara dengan pengawas $\mathrm{V}$ menjelaskan bahwa pelaksanaan supervisi yang dilakukan pengawas $\mathrm{V}$ dimulai dengan tahap perencanaan dengan melakukan kunjungan awal ke sekolah binaan sebagai bahan penyusunan program supervisi kepengawasan untuk wilayah V. Kunjungan awal yang dilakukan pengawas V menghasilkan kesepakatan waktu semua sekolah untuk mengadakan pertemuan dalam rangka pembentukan kepengurusan Kelompok Kerja Kepala Sekolah (K3S) untuk kepala sekolah dan Kelompok Kerja Guru (KKG) untuk guru sebagai bagian dari program supervisi pengawas, selain program tahunan dan program semester.

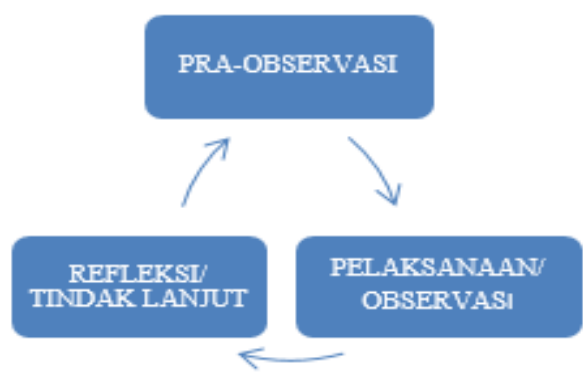

\section{Gambar 6 Model Supervisi Akademik Pengawas VI}

Hasil wawancara peneliti dengan pengawas VI, peneliti menemukan bahwa tahap perencanaan dilakukan pengawas VI dengan menyusun program supervisi seperti program tahunan dan program semester. 
Adapun model supervisi akademik pengawas pada Taman Kanak-kanak di Kota Palopo dapat peneliti gambarkan sebagai berikut:

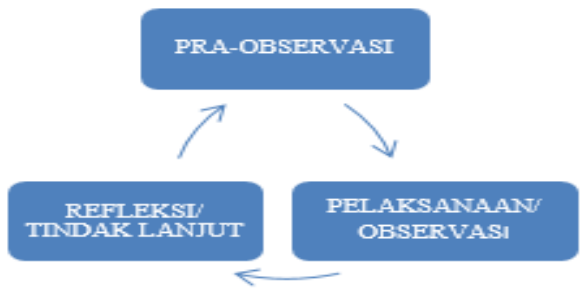

\section{Gambar 7 Model Supervisi Akademik Pengawas TK se-Kota Palopo}

Berdasarkan model supervisi di atas, peneliti menyimpulkan bahwa model supervisi akademik yang diterapkan pengawas pada guru Taman Kanak-kanak di Kota Palopo adalah model supervisi tradisional/konvensional, yang dalam pelaksanaannya belum maksimal.

\section{a. Temuan Hasil Supervisi Akademik Pengawas pada Guru Taman Kanak-kanak di Kota Palopo}

Dari hasil wawancara dan studi dokumentasi terhadap pelaksanaan supervisi pengawas pada taman kanak-kanak di Kota Palopo, peneliti dapat menggambarkan hal-hal yang merupakan temuan pengawas dalam pelaksanaan supervisi, yaitu :

Temuan pengawas I setelah melaksanakan supervisi pada guru taman kanak-kanak di bahwa penggunaan metode mengajar guru masih kurang, dalam menyusun Rencana Pelaksanaan Pembelajaran Harian (RPPH) sudah sesuai dengan kurikulum yang berlaku tetapi dalam mengimplementasikan dalam proses pembelajaran terkadang tidak sesuai dengan apa yang ada di RPPH. Selain itu penyediaan media pembelajaran oleh guru masih terbatas karena kurangnya kemampuan guru untuk membuat media pembelajaran, sehingga guru mengalami kesulitan dalam proses pembelajaran.

Pengawas II menjelaskan bahwa guru taman kanak-kanak di wilayah II saat dilakukan supervisi, adminitrasi guru tidak lengkap, sistem penilain guru tidak maksimal karena banyaknya aspek-aspek yang harus dinilai, selain itu ada guru yang tidak menyediakan media pembelajaran. Melalui wawancara, Pengawas III menjelaskan bahwa temuan dalam pelaksanaan supervisi akademik yaitu administrasi pembelajaran guru tidak lengkap, guru kurang kreatif dalam menggunakan media karena penggunaan buku paket yang lebih dominan namun hal tersebut juga disebabkan oleh kemampuan keuangan sekolah dalam menyediakan media pembelajaran. 
Selanjutnya berdasarkan dokumentasi berupa instrumen hasil supervisi pelaksanaan pembelajaran di kelas, pada TK Pelangi Bara, TK Tunas Harapan, dan TK Bukit Ratulangi, pengawas III, menemukan permasalahan guru pada ketiga TK tersebut hampir sama. Pengawas III menggambarkan bahwa guru masih kurang dalam kegiatan pendahuluan berupa apersepsi dan motivasi yaitu guru tidak menyampaikan manfaat materi, guru tidak mendemonstrasikan sesuatu yang terkait dengan tema, sedangkan pada kegiatan inti berupa penguasaan materi pembelajaran, guru tidak mengaitkan materi dengan pengetahuan yang relevan, perkembangan iptek, dan kehidupan nyata. Dan pada kegiatan penutup, guru tidak memberi tes lisan atau tulisan.

Temuan pengawas $\mathrm{V}$ yaitu adanya ketidaksesuaian antara administrasi pembelajaran dan implemetasi pembelajaran, dalam hal ini RPPH sudah benar tapi tidak sesuai dengan apa yang diajarkan oleh guru. Selain itu pemanfaatan media yang masih kurang.

Selanjutnya yang menjadi temuan pengawas VI berdasarkan studi dokumentasi instrumen supervisi pelaksanaan pembelajaran di TK Kasih Ibu yaitu pada kegiatan apersepsi dan motivasi guru tidak mengajukan pertanyaan yang menantang, guru tidak menyampaikan manfaat materi, guru tidak menyampaikan kemampuan yang akan dicapai peserta didik. Pada kegiatan inti, guru masih kurang dalam kemampuan mengaitkan materi dengan pengetahuan lain yang relevan, perkembangan Iptek, dan kehidupan nyata., selanjutnya guru tidak menfasilitasi kegiatan yang memuat komponen eksplorasi, elaborasi dan konfirmasi, pada kegiatan saintifik, guru tidak memancing pserta didik untuk bertanya, guru tidak memfasilitasi pserta didik untuk menganalisis, guru tidak menunjukkan keterampilan dalam penguasaan media pembelajaran. Pada kegiatan penutup, guru tidak memberikan tes lisan dan tulisan. Sedangkan temuan pengawas VI berdasarkan studi dokumentasi instrument supervisi pembelajaran di TK Satu Atap songka yaitu, pada kegiatan pendahuluan berupa apersepsi dan motivasi, guru tidak menyampaikan manfaat materi pembelajaran, guru tidak menyampaikan kemampuan yang kan dicapai peserta didik. Pada kegiatan inti, guru tidak memfasilitasi kegiatan yang memuat komponen eksplorasi, elaborasi, dan konfirmasi, pada penerapan pendekatan scientific, guru tidak memancing peserta didik untuk bertanya, guru tidak memberikan pertanyaan peserta didik untuk menalar (proses berfikir yang logis dan sistematis). Pada kegiatan penutupan pembelajaran, guru tidak memberikan tes lisan dan tulisan. Temuan pengawas VI terhadap kedua TK tersebut, pada dasarnya memiliki kesamaan. 

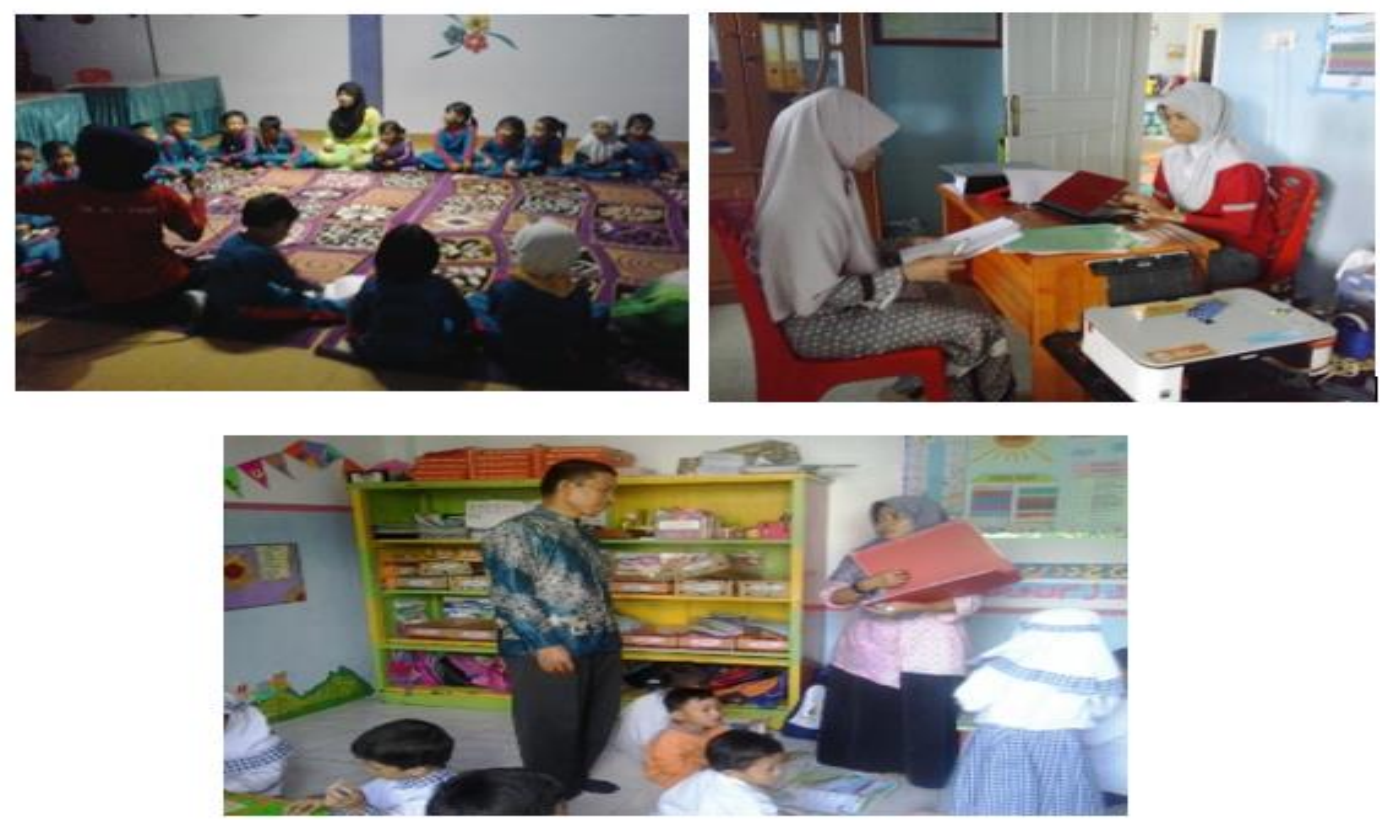

\section{Simpulan dan Saran}

Berdasarkan hasil penelitian dapat disimpulkan beberapa hal sebagai berikut:

1. Model supervisi akademik yang diterapkan pengawas taman kanak-kanak Kota Palopo dalam meningkatkan kompetensi guru Taman Kanak-kanak di Kota Palopo adalah model supervisi tradisional/konvensional, dengan menggunakan teknik langsung yang dilaksanakan melalui tiga tahap yaitu, pra observasi, observasi dan refleksi/tindak lanjut. Pelaksanaan model supervisi tradisional oleh pengawas Taman Kanak-kanak di Kota Palopo belum maksimal. Hal tersebut dapat digambarkan sebagai berikut:

2. Usaha yang dilakukan pengawas untuk meningkatkan kompetensi guru Taman Kanakkanak di Kota Palopo belum maksimal. Hal ini karena usaha yang dilakukan pengawas Taman Kanak-Kanak untuk meningkatkan kompetensi guru Taman Kanak-Kanak di Kota Palopo berupa pembinaan pengawas, hanya dilaksanakan dalam kegiatan Kelompok Kerja Guru (KKG), kegiatan-kegiatan Workshop atau pelatihan sangat jarang dilaksanakan.

3. Faktor pendukung pelaksanaan supervisi tidak signifikan hanya berupa dukungan kepala dinas pendidikan berupa motivasi tentang tanggung jawab terhadap pembinaan kepala sekolah dan guru Taman Kanak-kanak. Dukungan lain yang diberikan Kepala Dinas Pendidikan Kota Palopo berupa pemberian transpor. Selain itu dukungan kepala sekolah dan guru berupa sikap penerimaan kepala sekolah dengan kedatangan pengawas ke sekolah sedangkan faktor penghambat pelaksanaan supervisi akademik pengawas secara 
umum adalah ketidaksiapan guru dalam menyediakan kelengkapan administrasi pembelajaran, selain itu perubahan wilayah kepengawasan yang dilaksanakan pada pertengahan semester berpengaruh pada program supervisi pengawas dan jadwal supervisi pengawas yang telah disusun.

Berdasarkan kesimpulan dan implikasi penelitian di atas, maka penulis memberikan beberapa saran sebagai berikut:

1. Pengawas Taman Kanak-kanak di Kota Palopo, hendaknya selalu meningkatkan kompetensi supervisi akademik terutama yang berkaitan dengan model-model supervisi akademik dalam melakukan pembinaan dan penilaian terhadap guru Taman Kanak-kanak di Kota Palopo.

2. Model supervisi kontemporer/klinis, hendaknya perlu dipertimbangkan untuk diterapkan oleh pengawas dalam membina guru Taman Kanak-kanak di Kota Palopo.

3. Sebelum pelaksanaan supervisi, pada tahap pra observasi, hendaknya pengawas melaksanakan pertemuan awal dengan guru yang akan disupervisi sebelum pelaksanaan supervisi.

4. Penggunaan instrumen supervisi pelaksanaan pembelajaran hendaknya tidak hanya pada saat supervisi terpadu saja, tetapi setiap kali melaksanakan supervisi sehingga pelaksanaan supervisi berjalan maksimal, terfokus dan terarah.

5. Kepala Dinas Pendidikan Kota Palopo, hendaknya memfasilitasi guru dalam kegiatan pelatihan dan kegiatan-kegiatan lain demi peningkatkan kompetensi guru Taman Kanakkanak di Kota Palopo.

Untuk mengatasi permasalahan dalam pelaksanaan supervisi, Kepala sekolah hendaknya menjalankan salah satu fungsinya di sekolah yaitu fungsi supervisi, memberikan pembinaan, motivasi dan pemahaman kepada guru untuk selalu berubah kearah yang lebih baik sehingga pada saat pengawas akan melaksanakan supervisi, ketidaksiapan guru untuk disupervisi bukan kendala dalam pelaksanaan supervisi.

\section{Ucapan Terima Kasih}

Ucapan terima kasih kepada Universitas Muhammadiyah Palopo yang telah ikut berpartisipasi dalam penelitian pengabdian masyarakat ini mulai dari awal penelitian sampai selesai. Dan juga pemerintah setempat yang telah membantu proses adminstrasi dalam penelitian ini. Serta pengawas, kepala sekolah dan guru yang telah bersedia memberikan waktunya 


\section{Daftar Pustaka}

Fathurohman, P. (2011). Supervisi Pendidikan dalam Pengembangan Proses Pengajaran. Bandung: Refika Aditama.

Novi mayasari. (2016). Pembinaan Guru oleh Pengawas Sekolah Dasar Melalui Supervisi Akademik.

Sahertian, P. (2010). Konsep Dasar teknik Supervisi Pendidikan dalam rangka Pengembangan Sumber Daya Manusia. Jakarta: Rineka Cipta.

Wukir. (2013). Manajemen Sumber Daya Manusia dalam Organisasi Sekolah. Yogyakarta: Multi Presindo. 